\title{
EXPERIENCES OF SHORT COURSES OFFERED FOR SMALL FARMERS
}

\author{
József Kozári PhD'1, - Krisztina Tóth PhD² \\ (1) associate professor, ${ }^{(2)}$ associate professor \\ Faculty of Economics and Social Sciences, Szent István University \\ E-mail: kozari.jozsef@gtk.szie.hu, toth.krisztina@gtk.szie.hu
}

\begin{abstract}
Our research was made at the Regional Extensional Centre of Szent István University, which coordinates the extensional tasks of the Central-Hungarian Region and takes part in the New Hungarian Rural Development Programme (ÚMVP), as a training location. To make programmes successful registered advisors are involved, who also represent themselves as trainers in the training programmes. In this research we have rated 28 training programmes and the work of 13 registered trainers who took part in these programmes.
\end{abstract}

Keywords: consultancy, extension centres, training programmes

\section{Introduction}

Nowadays agricultural professional training, research and the system of agricultural extension have the task to explore, analyse and select the latest agricultural knowledge that are worth disseminating.

Our research work was carried out in the Regional Extension Centre of Szent István University, which has been coordinating the extensional tasks in the Central Hungarian Region since 1999. 2009 it was awarded the title „Training Centre” announced by the New-Hungarian Rural Development Programme (Új Magyarország Vidékfejlesztési Program/ÚMVP). Since then the list of tasks was compoleted by the organisation of compulsory and recommended trainings for agricultural producers. Our research work aims to investigate the role of the advisors in the organisation and implementation of farmer training programmes.

research work shows the institutional structure of the Hungarian extension system, the conditions of getting rolled in the Hungarian Register of Advisors, professional requirements for the advisors, the implementation process of trainings and the relevant advisors' tasks.

The investigated trainings were organised in the first quarter of 2013. During the period of investigation 28 compulsory trainings were conducted with the remarkable contribution of the advisors in organisation and training. 646 farmers completed the compulsory trainings with the assistance of 13 registered advisors.

\section{Methods}

The research work was carried out in the Regional Extension Centre of Szent István University (further as: SZIE RSZK).

The following research methods were applied:

- We reviewed the relevant Hungarian literature, the existing legislation on ÚMVP trainings as well as the registry conditions for advisors. 
- We interviewed the registered advisors involved into the investigation and surveyed the methods of knowledge transfer they used in their extension work.

- We participated in the compulsory trainings and collected first hand experience about the relation of the farmers to the compulsory trainings.

- We processed the data base of the AKG-trainings included into the SZIE RSZK Training Project of 2012.

\section{Results}

The structure of the Hungarian Extension System

The present structure of the Hungarian Extension System is governed by the FVM (Ministry of Agriculture and Rural Development) regulation of 73/2007 (VII. 27.). Figure 1 shows the structure of the system.

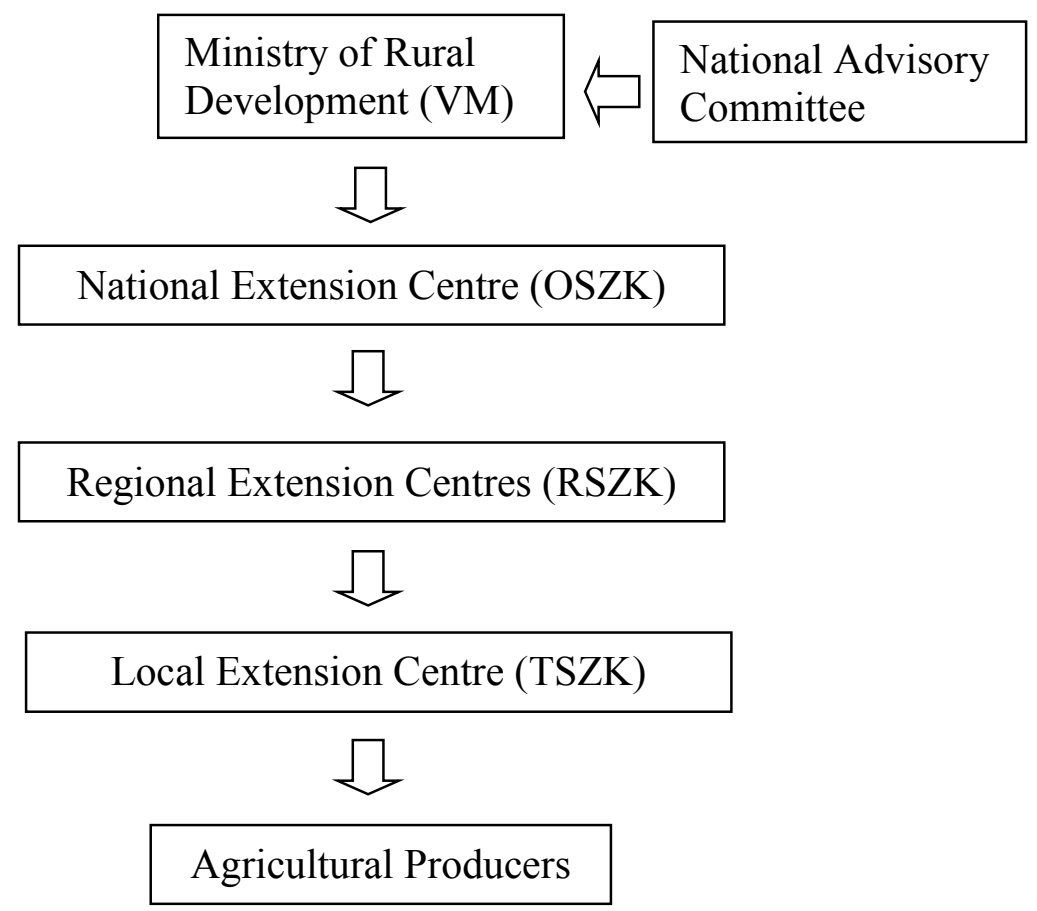

Figure 1: Structure of the Hungarian Extension

Source: Own Source 2013

Conditions of being enrolled and staying in the Registry of Advisors

Enrolment in the Registration of the advisors follows after application. The registry includes the main data of advisors who have had the required degree in higher education as well as the practice and have not been involved in agricultural broking at all. Last year the National Extension Committee elaborated a recommendation about the modification of the yearly compulsory training for the registered advisors. This compulsory training happens in a credit system. 
Table 1: Credit points, 2013

\begin{tabular}{|l|l|c|}
\hline Type of the event & & Credits \\
\hline Conferences & national & 6 \\
\cline { 2 - 3 } & regional & 4 \\
\hline $\begin{array}{l}\text { Technical and technological } \\
\text { demonstrations }\end{array}$ & national & 6 \\
\cline { 2 - 3 } & regional & 4 \\
\hline Variety shows & & 4 \\
\hline Forums actual & & 3 \\
\hline Introduction of innovations & & 5 \\
\hline $\begin{array}{l}\text { Trainings related to } \\
\text { tasks (e.g. filling in GN, e- }\end{array}$ & & 4 \\
\hline Software shows journal & & $3 / \mathrm{pcs}$ \\
\hline Vocational and & & 6 \\
\hline Agricultural national & \\
\hline Special exhibitions and fairs & regional & 3 \\
\hline Farmer days & national & 6 \\
\cline { 2 - 3 } & regional & 3 \\
\hline
\end{tabular}

Source: VKSZI, 2013

Trainings founded by the European Agricultural and Rural Development Funds and related to the New-Hungarian Rural Development Programme

There are two types of financially supported trainings: optional and compulsory. Among the optional trainings we can find trainings offering vocational knowledge (so called recommended trainings) and those offering an OKJ certificated or official trainings. In our research work we show the experiences gained of the compulsory trainings belonging to the $2^{\text {nd }}$ target area.

Eligible for financial support are agricultural producers and forest managers who have a registry number at Agricultural Rural Development Office (further on NVH) and have a farmers' card at least.

NVH handed over the list of farmers obliged to trainings to SZIE ÚMVP Centre.

\section{Experiences gained of the AKG compulsory trainings organised by SZIE ÚMVP Centre}

The ÚMVP Centre of Szent István University received the names and availability of 535 clients from MVH in order to organise compulsory trainings of AKG 2. As a result of informative letters about $50 \%$ of the clients applied for the trainings. In order to raise the rate of the participation registered advisors were involved into the organisation and they also informed their own clients about the trainings. As a result the numbers of participants increased up to 646. Figure 2 shows the numbers of new clients in new counties included by SZIE ÚMVP Centre. Thanking to the work of the registered advisors SZIE ÚMVP Centre was able to increase the number of clients up to $120 \%$. 


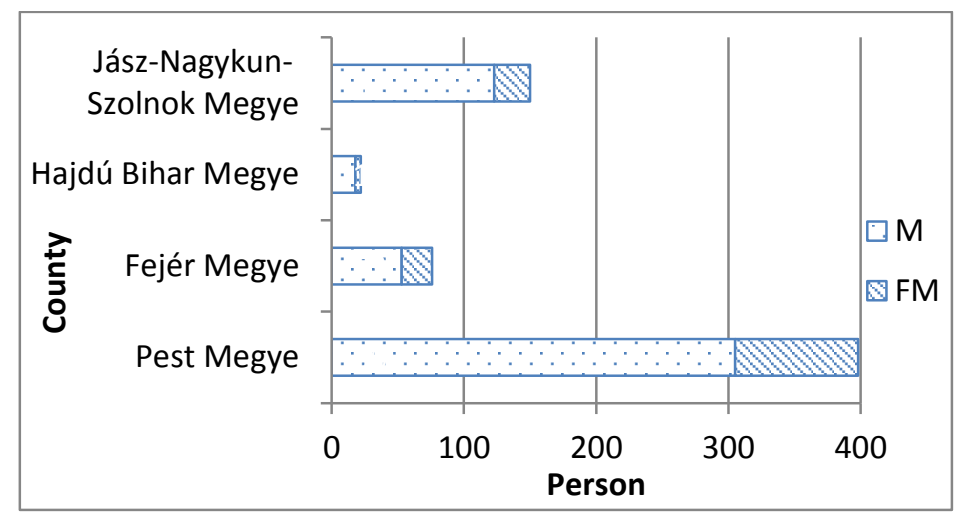

Figure 2: AKG trainings according to gender

Source: SZIE ÚMVP Training Centre, 2013.

When choosing the locations for the trainings we aimed to reduce the distance of clients' travelling to a minimum but also to offer the best suitable technical conditions of education that ensure the highest level of training. The training courses were organised in educational institutions, community centres or in lecture rooms of self-governments in general.

\section{Experiences of interviewing advisors}

Advisors considered important that their clients get to know them in the role of the trainer as well, and trainings also enlarged the number of their own clients in many of the cases.

Advisors can participate as trainers in financially supported trainings after they had applied at a ÚMVP Training Organisation and successfully passed the examination on the teaching material of the relevant compulsory training course. 13 out of the trainers registered by SZIE ÚMVP Centre passed the examination by AKG II compulsory training in the system of NAKVI successfully.

They generally notified their existing clients by phone and at a lower rate in e-mail about the available training courses. $100 \%$ of the clients informed by the advisors appeared at the trainings. This shows that there is a high level of professional confidence between the clients and the advisors.

\section{Conclusions}

646 farmers attended the 28 compulsory training courses that were organised by SZIE ÚMVP Centre. The high numbers of participants were due to the fact that we involved registered advisors that also brought new and their own clients to the trainings. As a result of involving the advisors Szent István University, as a Training Centre, could gain area in further two counties (Hajdú-Bihar- and Jász-Nagykun-Szolnok) and could increase their awareness and professional credit as well. We will be able to rate this latter one by the increase of the number of optional training courses. Advisors are pleased to act as trainers before their clients, especially if they are entitled by a higher educational institution. A further advantage is that they can enlarge the number of their clients through the trainings. Involving the registered advisors into the organisation and implementation of the training courses greatly increased the numbers of clients of SZIE ÚMVP Training Centre. Therefore we recommend relying on the active participation of the registered advisors in the compulsory trainings of $2^{\text {nd }}$ target area in future as well. 


\section{References}

1. Kozári J. (Szerk.) (2000/a): A mezőgazdasági szaktanácsadás fogalma. Szaktanácsadás a mezőgazdaságban. Budapest: Dinasztia Kiadó., 13-14 p.

2. Tóth K. (2005): Az Agrár-szaktanácsadás helye a mezőgazdasági ismereti rendszerben, fejlesztési lehetőségeinek megalapozása Magyarországon. Doktori disszertáció 100-101. p.

3. Vér A. (2013): Az Agrár-szaktanácsadási rendszerek vizsgálata és értékelése 47-51p

4. vkszi.hu: Letöltés dátuma: 2013. 05 08, forrás: http://www.vkszi.hu/umvpkepzes 2013.05.08

5. mvh.gov.hu: Letöltés dátuma: 2013. 0509.

6. http://www.mvh.gov.hu/.../1033836 1392008 FVM rendelet 201110032013.05 .09

7. umvp.eu.. Letöltés dátuma: 2013. 05. 08, forrás: http://www.umvp.eu 